Jurnal Konstruksi Hukum | ISSN: 2746-5055

Vol. 2, No. 2, Mei 2021, Hal. 290-295| Tersedia online di

https://www.ejournal.warmadewa.ac.id/index.php/jukonhum

DOI: https://doi.org/10.22225/jkh.2.2.3224.290-295

\title{
PENEGAKAN HUKUM TERHADAP MODIFIKASI KENDARAAN BERMOTOR OLEH SATUAN LALU LINTAS POLRES GIANYAR
}

\author{
I Made Hadiyanta Purnama Sardi, Anak Agung Istri Agung, Ida Ayu Putu Widiati \\ Fakultas Ilmu Hukum Universitas Warmadewa \\ hadiyanta835@gmail.com,notistria@yahoo.com, idaayuputuwidiati@gmail.com
}

\begin{abstract}
Abstrak
Maraknya modifikasi kendaraan bermotor dapat menimbulkan dampak negatif jika kurangnya pemahaman dari masyarakat, yang dapat membahayakan pengendara di jalan raya. Setiap orang yang ingin melakukan modifikasi kendaraan bermotor, diwajibkan memiliki izin sebagaimana persyaratan dalam Undang-undang Nomor 22 Tahun 2009 tentang Lalu Lintas dan Angkutan Jalan. Permasalahan dalam penelitian ini adalah 1) Jenis modifikasi kendaraan bermotor yang melanggar peraturan lalu lintas. 2) Penegakan hukum terhadap modifikasi transportasi yang melanggar peraturan lalu lintas oleh Satlantas Polres Gianyar. Tujuan penelitian ini untuk menambah wawasan dalam modifikasi kendaraan bermotor sesuai dengan aturan yang berlaku. Penelitian ini menggunakan metode empiris dan menggunakan pendekatan sosiologi hukum. Hasil penelitian menunjukkan modifikasi kendaraan bermotor harus dilakukan uji tipe ulang, dan apabila tidak melakukan uji tipe maka sudah melanggar pasal 50 ayat (1) Undang-undang Nomor 22 Tahun 2009 tentang Lalu Lintas dan Angkutan Jalan. Kemudian penegakan hukum terhadap modifikasi kendaraan bermotor sudah optimal, akan tetapi masih terdapat beberapa faktor yang menghambat penegakan, seperti kurangya kerjasama dari masyarakat dan kurangnya kesadaran masyarakat.
\end{abstract}

Kata Kunci: Kendaraan Bermotor, Modifikasi, Penegakan Hukum.

\begin{abstract}
The rise of motorized vehicle modification can have a negative impact if there is a lack of understanding from the public, which can endanger motorists on the road. Every party who wishes to modify a motorized vehicle is required to have a permit as required in Law Number 22 of 2009 concerning Road Traffic and Transportation. The problems in this thesis are 1) The types of motor vehicle modifications that violate traffic regulations 2) The law enforcement against motorized vehicle modifications that violate the traffic regulations by the Gianyar Police Traffic Police The purpose of this research is to add insight into motorized vehicle modification in accordance with applicable regulations. This study uses an empirical method and uses a sociology of law approach. The results showed that the modification of motorized vehicles had to be subjected to a retype test, and, tit did not carry out the type test it would have violated Article 50 paragraph (1) of Law Number 22 Year 2009 concerning Road Traffic and Transportation. Then law enforcement on motor vehicle modification has been optimal, but there are still several factors that hinder enforcement.
\end{abstract}

Keywords: Law Enforcement, Modification, Motorized Vehicles

\section{PENDAHULUAN}

Perkembangan transportasi yang terjadi akibat kebutuhan dari setiap individu untuk berpergian ke suatu tempat lain mencari barang yang sedang dibutuhkan maupun hanya sekedar melakukan aktivitas sehari-hari, serta mendistribusikan barang ke suatu tempat yang membutuhkan barang tersebut. Transportasi sebagai salah satu komponen yang sangat penting bagi setiap orang pada dewasa ini. Transportasi sudah dianggap sebagai bagian dari kehidupan manusia karena memiliki sifat berp indah-pindah sebagai makhluk sosial. Maka dapat dilihat betapa pentingnya aturan mengenai lalu lintas (Nasution, 2008: 1).

Kehadiran UU Latu Lintas adalah suatu hal mutlak untuk diberlakukan disetiap negara yang ada di dunia. Jika tidak memungkinkan akan banyak orang akan melanggar lalu lintas dalam setiap aktivitas masyarakat. Setiap orang akan bersikap sesukanya tanpa memperhatikan dan menghiraukan keadaan orang lain di sekitar. Dampak yang ditimbulkan karena perkembangan teknologi yang terjadi dewasa ini yakni perkembangan teknologi dalam dunia otomotif. Contoh nyata dari perkembangan teknologi otomotif dewasa ini yaitu dengan melakukan modifikasi terhadap kendaraan roda dua (sepeda motor) pada dasarnya tidak menghiraukan keselarnatan pada pengendara dan pengguna jalan lainnya, selain itu modifikasi tersebut tidak sesuai dengan ketentuan yang berlaku pada UU lalu lintas. 
Kehadiran dari suatu peraturan dianggap perlu sebagai pedoman untuk melakukan segala tindakan sehingga dapat digunakan sebagai pedoman dalam mengatasi suatu permasalahan yang terjadi (Kristiyanti, 2008).

Seiring berkembangnya jaman menjadikan fungsi dari kendaraan bermotor yang dahulunya hanya dijadikan sebagai alat transportasi, tetapi realita saat ini digunakan sebagai penunjang penampilan dari pemiliknya. Hal ini merupakan ciri pergeseran fungsi dari kendaraan bermotor dewasa ini (Mahdi, 2016). Pola pikir manusia yang semakin maju \& kreatif seiring perkembangan zaman, membuat manusia memiliki ide serta gagasan yang dapat menghasilkan suatu produk (Mahasin, 2019) Tampilan asli dari sepeda motor terkadang kurang memiliki kepuasan tampilan bagi pemiliknya, sehingga timbul keinginan untuk dilakukannya suatu modifikasi khusus terhadap sepeda motornya agar mendapatkan kepuasan tersendiri ketika digunakan. Marak dilakukannya modifikasi kendaraan bermotor yang terjadi pada kalangan anak muda maupun orang dewasa bahkan pedagang yang menggunakan kendaraannya sebagai sarana untuk berjualan saat ini akan memberikan banyak dampak yang negatif jika minimnya pemahaman mengenai memodifikasi kendaraan bermotor sesuai dengan aturan yang berlaku dan tentunya berpotensi membahayakan pengendara tersebut dan pengendara lainnya akibat dari modifikasi yang dilakukan tidak berdasarkan pada standar dan ketentuan yang telah diatur dalam UU Lalu Lintas.

Saat ini modifikasi kendaraan bermotor tidak hanya dilakukan oleh anak remaja, narnun ketertarikan orang-orang dewasa juga tertarik untuk melakukan suatu modifikasi khusus terutama bagi seseorang yang tergabung dalarn anggota suatu paguyuban atau organisasi kendaraan bennotor baik yang resmi maupun tidak resmi. Namun tidak dipungkiri banyak juga masyarakat yang bermata pencaharian sebagai pedagang yang menggunakan kendaraan sebagai sarana dan alat untuk berjualan, sehingga dapat dikatakan sebagai modifikasi karena merubah suatu bentuk dari kendaraan tersebut yang berpotensi membahayakan pengendara tersebut maupun pengguna jalan lainnya.

Proses ketika melakukan modifikasi khusus dari yang ringan hingga yang benar-benar merubah hampir semua tampilan semua tampilan sepeda motor bukan merupakan suatu fenomena yang tabu yang terjadi dewasa ini. Tujuan dilakukan modifikasi adalah ada yang hanya untuk sekedar hobi atau keinginan untuk mengikuti perkembangan di sekitar lingkungan tempat tingga mereka. Akan tetapi, sebenarnya modifikasi kendaraan tidak dapat dilakukan secara sembarangan karena terdapat regulasi yang mengatur pelaksanannya (Matthews, 2020). Pada dasarnya hukum harus menjadi sebuah cerminan dan pedoman dalam perubahan moralitas sosial.

Hukum merupakan suatu ringkasan yang menggambarkan sebuah himpunan yang mutlak dan fleksibel berdasarkan prinsip, norrna-norma, ide-ide, kebiasaan dan aturan-aturan yang diharap mampu mengendalikan tatanan kehidupan sosial dalam masyarakat. Berdasarkan UU Nomor 2 Tahun 2002 tentang Kepolisian Negara Republik Indonesia dijelaskan bahwa Lembaga Kepolisian Negara Republik Indonesia diberikan wewenang unruk melaksanaan identifikasi atau pengecekan terhadap persyaratan teknis berupa kelengkapan dan jalan suatu kendaraan bermotor. Meskipun memodifikasi kendaraan bermotor bukan tergolong sebagai suatu perbuatan yang jahat, namun perbuatan tersebut perlu dipantau dan diawasa guna mencegah perilaku yang menyimpang dalam masyarakat yang berbeda mengenai nilai dan fungsi sparepart atau komponen-komponen buatan asli pabrik resmi atas sepeda motor yang dapat memastikan keselamatan pada saat digunakan. Secara sosiologis-yuridis nampaknya terjadi suaru perkembangan wilayah perkotaan yang relatif pesat di indonesia.

Perkembangan tersebut ditandai dengan terjadinya suatu pengembangan wilayah, peningkatan dan kwalitas kehidupan serta pertambahan fasilitas fisik. Maksud dari fasilitas fisik tersebut yaitu banyaknya kendaraan dan angkutan umum di kota-kota metropolitan. Pertambahan angka penduduk yang begitu pesat di kota harus dibarengi dengan pengembangan sarana-prasarana kota yang serasi. Prasarana itu antara lain mencangkup jalan, alat komunikasi, dan angkutan umum. Lalu lintas dapat diartikan sebagai sebuah gerak kendaraan dan orang di ruang lalu lintas jalan raya, sebagaimana diatur dalarn Pasal I ayat (I) UU Latu Linta Nomor 22 Tahun 2009 tentang Latu Lintas dan Angkutan Jalan. Sedangkan yang dirnaksud mengenai ruang lalu lintas jalan adalah prasarana yang diperuntukan bagi gerak pindah kendaraan, orang, dan atau barang yang berupa jalan dan fasilitas lainnya sebagai pendukung, sebagaimana diatur dalam pasal I ayat (11) UU Lalu Lintas Nomor 22 Tahun 2009 tentang Lalu Lintas dan Angkutan Jalan. Selanjutnya, transportasi adalah kegiatan perpindahhan barang dan penumpang dari satu tempat ke tempat lainnya secara dinamis. Era globalisasi yang terjadi pada saat ini kegiatan setiap individu tidak dapat dilepaskan dari bantuan 
teknologi yang salah satunya merupakan alat transfortasi berupa kendaraan bermotor. Manusia menghadapi suatu kemajuan teknologi yang juga dibarengi dengan dampak negatifnya suatu kemajuan teknologi. Dalam hal ini peran dari pemerintah untuk menanggulangi dampak negatif yang ditimbulkan (Ali, 2002: 64).

Susunan aturan memiliki fungsi sebagai kontrol sosial, pengendali dan pedoman kehidupan masyarakat dengan tujuan agar terciptanya suatu tatanan kehidupan yang aman, tertib dan adil dengan adanya jaminan kepastian hukum dan perlindungan hak asasi manusia bagi setiap individu. Selain itu, tatanan hukum difokuskan terhadap pelakunya yang konkret, yaitu pelaku yang berbuat dan tatanan hukum harus memiliki sanksi yang tegas dan nyata dalam setiap urusan, termasuk dalam urusan lalu lintas. Negara Indonesia merupakan negara hukum, sebagaimana dimaksud dalam Pasal I ayat (3) UUD NRI 1945. Hal tersebut merupakan suaru landasan konstitusional bahwa Indonesia merupakan negara yang berlandaskan atas hukum, hukum ditempatkan sebagai panglima tertinggi dalarn sendi kehidupan bermasyarakat, berbangsa dan bernegara (supremacy of law).

\section{METODE PENELITIAN}

Penelitian ini menggunakan penelitian hukum empiris. Penelitian hukum empiris merupakan suatu kajian yang memandang hukum sebagai kenyataan, mencakup kenyataan sosial, kenyataan kultur dan lain-lain. Tidak hanya itu, riset empiris dapat digunakan buat mengamati hasil dari tingkah laku manusia berupa peninggalan aset raga ataupun arsip (Fajar \& Achmad, 2010).Penelitian hukum empiris dengan istilah lain biasa disebut sebagai penelitian hukum sosiologis ini bertolak dari data primer/dasar, yaitu data yang diperoleh ke lapangan, berupa pengamatan (observasi), ataupun wawancara (Efendi \& Ibrahim, 2016:149). Pendekatan sosiologi hukum adalah pendekatan yang digunakan guna mengamati aspek-aspek hukum dalam interaksi sosial masyarakat guna mengamati hukum yang dilaksanakan dengan mengamati langsung aktifitas modifikasi kendaraan bermotor yang terjadi di masyarakat (Ali, 2014: 105).

Mengenai sumber bahan hukum yang digunakan terbagi atas Bahan Hukum Primer adalah bahan hukum yang utarna yang menjadi dasar kajian dari penulisan penelitian ini. Data primer, yaitu data yang diperoleh peneliti secara langsung melalui subyek penelitian berupa hasil wawancara di lapangan. Melalui metode penelitian wawancara, dengan mengajukan beberapa pertanyaan guna memperoleh data-data yang langsung berhubungan dengan permasalahan yang sedang diteliti. Data primer sebagai data utama di dalam penelitian, dilakukan melalui teknik wawancara. Untuk melaksanakan teknik wawancara diawali dengan observasi terlebih dahulu ke lokasi penelitian, kemudian mempersiapkan daftar pertanyaan dan kemudian melakukan wawancara dengan pihak kepolisian, khususnya pimpinan dari Saruan Lalu Limas Polres Gianyar.

Data sekunder, adalah data yang diperoleh melalui penelitian kepustakaan (library research) yaitu dengan mengkaji bahan-bahan bacaan yang ada kaitannya dengan permasalahan hukum dalam penelitian ini yaitu dengan menganalisa peraturan perundang-undangan yang berlaku penelitian untuk menyempurnakan data yang di dapat dari lapangan. Data sekunder sebagai data penunjang di dalarn penelitian, dilakukan dengan studi dokumen yang berhubungan dengan penelitian, didapat dari perpustakaan serta dokumen ataupun artikel melalui penelusuran internet, kemudian dilakukan teknik pencatatan, meringkas, maupun mengutip. Lokasi penelitian ini bertempat di kantor satuan lalu lintas polres Gianyar, yang beralamat di Jalan Ngurah Rai Nomor 6, Gianyar. Populasi dalam penelitian ini adalah Satuan Lalu Lintas Polres Gianyar. Penelitian ini tidak meneliti semua populasi atau masyarakat, tetapi hanya beberapa masyarakat yang melanggar ketentuan UU Lalu Lint as pada Daerah Kabupaten Gianyar, oleh karena itu perlu dipilih beberapa sampel untuk dijadikan responden dengan cara menggunakan teknik non probability sampling (Soemitro, 1994:42).

Dalam menganalisa data yang sudah terkumpul slenajutnya dipergunakan teknik analisis kualitatif dengan mengumpulkan data baik yang bersumber dari data primer maupun data sekunder adalah data naruralistik yang terdiri atas kata-kata yang tidak diolah menjadi angka-angka. Dari seluruh data yang telah dikumpulkan, diuraikan dan ditata secara deskriptif kemudian disistemasikan yang selanjutnya dijadikan dasar dalam pengambilan kesimpulan. 


\section{HASIL DAN PEMBAHASAN}

\section{Jenis Modifikasi Kendaraan Bermotor yang Melanggar Peraturan Lalu Lintas}

Kurangnya kesadaran hukum pada masyakat membuat banyaknya terjadi pelanggaran hukum. Kesadaran hukum sebenarnya sebuah kesadaran atau nilai-nilai yang terdapat di dalam perilaku manusia tentang hukum yang ada atau tentang hukum yang diharapkan akan ada. Membahas fenomena memodifikasi kendaraan bermotor memang banyak kita lihat di kalangan masyarakat khususnya remaja, akan tetapi apakah semua jenis modifikasi bisa kita katakan melanggar aturan, contohnya saja dalam hal mengganti kaca spion. Mengganti kaca spion juga termasuk memodifikasi kendaraan akan tetapi apabila kaca spion tersebut masih bisa digunakan dengan semestinya maka itu tidak melanggar peraturan modifikasi.

Modifikasi kendaraan seperti merubah spion tidaklah melanggar peraturan modifikasi, selama spion tersebut memenuhi kriteria yang sudah ditegaskan pada Pasal 37 Peraturan Pemerintah Nomor 55 Tahun 2012, kalau hanya sekedar memakai aksesoris pada kendaraan bermotor maka modiifkasi tersebut tidak melanggar aturan. Modifikasi seringkali disalah gunakan untuk kepentingan dan hasrat individu. Faktor penyebab terjadinya pelanggaran tersebut kurangnya norma masyarakat serta kurangnya kesadaran masyarakat terhadap hukum yang berlaku. Jenis-jenis modifikasi pada kendaraan bermotor yang tergolong sebagai pelanggaran terhadap UU Lalu Lintas Nomor 22 Tahun 2009 tentang Lalu Lintas dan Angkutan Jalan adalah sebagai berikut:

\section{a. Merubah Kerangka Kendaraan}

Kerangka kendaraan/sasis adalah kerangka internal yang menjadi dasar produksi sebuah kendaraan, sebagai penunjang bagian-bagian lainnya meliputi mesin atau alar elektronik yang terdapat pada kendaraan bermotor yang merupakan desain resmi dari pabrik. Pada kendaraan bermotor terdapat bagian Sasis dapat dianalogikan dengan kerangka tulang pada binatang. Pada kendaraan bermotor seperti mobil, sasis terdiri atas kerangka bagian bawah mobil, roda, transmisi, sistem suspensi, mesin serta komponen lainnya yang terdapat pada kendaraan bermotor. sasis merupakan kerangka keras tempat dipasangnya papan induk, umumnya dalam bentuk kendaraan yang dimaksud merubah kerangka kendaraan termasuk melanggar aturan apabila bentuk kendaraan tersebut berubah dari bentuk aslinya, contohnya dari kendaraan roda dua yang dimodifikasi dengan menambahkan kerangka lain menajdi roda tiga bahkan membuat kendaran tersebut berubah karena alasan untuk mencari nafkah seperti untuk berjualan.

\section{b. Menambah kecepatan kendaraaan atau merubah mesin kendaraan}

Banyak di kalangan remaja memiliki rasa haus yang tinggi untuk memiliki kendaraan bermotor yang lebih cepat maka dari itu para remaja tersebut memodifikasi mesin mereka dengan melakukan modifikasi mesin kendaraan mereka agar kecepatannya bertambah. Mesin dapat diartikan sebagai alat mekanik atau elektrik yang mengirim atau mengubah energi untuk melakukan atau membantu pelaksanaan tugas manusia, masyarakat seakan tidak peduli dan memikirkan resikonya mengubah kendaraan mesin yang berdampak membahayakan bagi pengendara kendaraan bermotor dan pejalan kaki. Kendaraan bermotor dibuat di pabrik dengan standar keamanan dan memiliki batasan atau kemampuan yang telah ditentukan Agen Pemilik Merek kendaraan tersebut. Apabila ditambahakan atau dimodifikasi akan membuat mesin tersebut tidak akan bertahan lama sehingga membuat mesin tersebut mudah rusak, Mengubah mesin memang diperbolehkan apabila kendaraan tersebut hams mengubah mesin tersebut, yang dimaksudkan adalah bahwa mesin yang kita gunakan mengalarni gangguan atau kerusakan yang diharuskan mengganti mesin tersebut dan ada ketentuan yang berlaku untuk melakukan perubahan tersebut, seperti yang dijelaskan di atas, kendaraan bermotor apabila ingin mengubah mesin harus mengubah dengan mesin yang sama dan tipe sama serta harus di dilakukan uji kelayakan pada kendaraan tersebut apakah kendaraan tersebut aman unruk digunakan agar tidak membahayakan keselamatan pengendara lainnya.

\section{Penerapan Sanksi Terhadap Modifikasi Kendaraan Bermotor yang Melanggar Peraturan Lalu Lintas}

Sanksi memainkan peran penting dalam kerangka penegakan hukum (penegakan hukum) kepada pengacaranya sendiri dalam undang-undang. Secara umum, sanksi adalah hukum dalam bentuk ibadah karena pelanggaran aturan hukum. Dalam bidang hukum yang dikenal sebagai sanksi sipil, penjahat dan administrasi. Sanksi perdata adalah sanksi hukum yang diketahui seseorang dapat 
menyebabkan kerugian bagi orang lain, oleh karena itu orang yang menyebabkan kerugian harus mengganti kerugiannya.

Penegakan hukum dalam bidang lalu lintas dan angkutan jalan merupakan proses dilakukannya upaya untuk mengimplementasikan berfungsi norma-norma hukum bidang lalu lintas dan angkutan jalan secara nyata sebagai pedoman perilaku dalam penyelenggaraan lalu lintas dan angkutan jalan. Penindakan pelanggaran lalu lintas yang dilakukan oleh Satlantas Polres Gianyar khususnya Unit Turjawali dilaksanakan melalui mekanisme-rnekanisme yang telah ditetapkan sesuai dengan perundang-undangan baik secara umum maupun khusus. Secara umum penindakan pelanggaran lalu lintas yang dilaksanakan mengacu pada KUHAP dan KUHP sedangkan secara khusus lebih mendalam diatur dalam peraturan-peraturan lainnya, yaitu UU Lalu Lintas dan Angkutan Jalan No. 22 Tahun 2009, dan PP Nomor 80 Tahun 2012 tentang Tata Cara Pemeriksaan Kendaraan Bermotor di Jalan dan Penindakan Pelanggaran Lalu Lintas dan Angkutan Jalan.

Penegakan hukum bisa juga sering dilakukan dengan cara melakukan patroli lalu lintas yang merupakan metode utama yang diterapkan oleh kepolisian dalam menjalankan tugas lalu lintas maupun mengawasi lalu lintas. Berdasarkan hasil wawancara yang dilakukan kepada KBO Lantas Polres Gianyar, IPTU I Gede Budarasa, menjelaskan bahwa dalam penindakan pelanggaran lalu lintas terhadap kendaraan bermotor yang dimodifikasi sudah cukup baik dan efiesien, tinggal pengoptimalisasian yang perlu ditingkatkan. Salah satu cara yang kami laksanakn yaitu memberikan teguran berupa pembinaan maupun hukuman fisik, namun apabila teguran tersebut tidak memberi efek jera terhadap pelanggar maka akan diberikan tindakan yuridis yaitu dengan memberikan hukuman berupa penilangan sesuai dengan peraturan perundang-undangan yang berlaku.

Satlantas Polres Gianyar tidak henti-hentinya selalu melakukan penertiban atau operasi kendaraan bermotor. Operasi ini dilakukan guna mengurangi pelanggaran lalu lintas khususnya dalam hal modifikasi kendaraan bermotor, serta mengurangi angka kecelakaan, menciptakan keamanan, keselamatan, ketertiban, maupun kelancaran lalu lintas. Operasi ini juga disebut sebagai razia kendaraan atau pemeriksaan kendaraan. Pengaturan mengenai razia ini tercantum dalam Peraturan Pemerintah Nomor 80 Tahun 2012 tentang Tata Cara Pemeriksaan Kendaraan Bermotor di Jalan dan Penindakan Pelanggaran Lalu Limas dan Angkutan Jalan. Pemeriksaan kendaraan atau razia kendaran ini bertujuan untuk:

1. Terpenuhinya persyaratan teknis dan layak jalan kendaran bermotor

2. Terpenuhinya kelengkapan dokumen registrasi dan identifikasi pengemudi dan kendaraan bermotor serta dokumen perizinan dan kelengkapan kendaraan bermotor angkutan umum;

3. Terdukungnya pengungkapan perkara tindak pidana; dan

4. Terciptanya kepatuhan dan budaya keamanan dan keselamatan berlalu lintas.

Dalam modifikasi kendaraan bermotor yang dimaksud dengan modifikasi kendaraan bermotor yaitu perubahan terhadap kelengkapan kendaraan bermotor seperti kaca spion, klakson, lampu utama, lampu mundur, lampu rem, lampu penunjuk arah, alat pemantul cahaya, maupun alat pengukur kecepatan. Namun apabila modikasi kelengkapan tersebut tidak mernenuhi persyaratan atau dapat dikatakan rnelanggar peraturan maka dapat dikenakan sanksi sesuai dengan Pasal 285 ayat (I) Undang-undang Nomor 22 Tahun 2009 yaitu: Setiap orang yang mengemudikan Sepeda Motor di Jalan yang tidak rnemenuhi persyaratan teknis dan laik jalan yang meliputi kaca spion, kJakson, lampu utama, lampu rem, lampu penunjuk arah, alat pemantul cahaya, alat pengukur kecepatan, knalpot, dan kedalaman alur ban sebagaimana dimaksud dalam Pasal 106 ayat (3) juncto Pasal 48 ayat (2) dan ayat (3) dipidana dengan pidana kurungan paling lama I (satu) bulan atau denda paling banyak $\mathrm{Rp} 250.000,00$ (dua ratus lima puluh ribu).

Berdasarkan hasil wawancara dengan KBO Lantas Polres Gianyar, IPTU I Gede Budarasa, menjelaskan memodifasi kendaraan bermotor sebenarnya sudah termasuk melanggar aturan, sebab memodifikasi kendaraan bermotor dapat dikatakan juga rnelanggar hak paten dari kendaraan tersebut, karena sudah merubah tampilan atau bentuk dari kendaraan tersebut. Dapat diketahui juga rnemodifikasi kendaraan bermotor juga dapat membahayakan bagi pengguna kendaraan tersebut maupun pengguna jalan yang lainnya. Akan tetapi jika dilihat dari sisi positifnya, modifikasi kendaraan bermotor sebagai ajang kreatifitas yang nanti akan dipamerkan pada acara kontes-kontes motor. 
Dalam melakukan penindakan terhadap pelanggaran lalu lintas khususnya dalam hal modifikasi kendaraan bermotor, Kepolisian Satlantas Polres Gianyar terkadang tidak serta merta melakukan tindakan hukum karena faktor situasi maupun keadaan. Seperti situasi pandemi Covid saat ini Satlantas Polres Gianyar lebih melakukan pembinaan terhadap pelanggar dengan memberikan himbauan maupun edukasi akan bahayanya modifikasi kendaraan bermotor yang melanggar peraturan laJu lintas maupun memberikan hukurnan fisik berupa push up atau squat jump, agar dapat memberikan efek jera dan agar tidak melalukan perbuatannya lagi.

\section{SIMPULAN DAN SARAN}

\section{Simpulan}

Jenis modifikasi kendaraan bermotor yang melanggar peraturan lalu lintas adalah modifikasi yang merubah kerangka kendaraan, menambah kecepatan kendaraan atau mengubah mesin kendaraan, kebisingan emisi gas buang, serta hilangnya fungsi penting pada kendaraan tersebut yang yang setelah diilakukan tes uji tipe kelaikan dari kendaraan bermotor tersebut dinyatakan membahayakan masyarakat dan pengguna jalan, yang mana dikategorikan sebagai melanggar peraturan lalu lintas.

Apabila kendaraan bermotor dimodifikasi haruslah sesuai dengan ketentuan yang telah ditetapkan dan jika tidak sesuai atau melanggar peraturan dapat dikenakan sanksi sesuai dengan pasal 285 ayat (1) Undang-Undang Nomor 22 Tahun 2009. Penegakan hukum terhadap modifikasi kendaraan bermotor yang melanggar peraturan lalu lintas oleh Satlantas Polres Gianyar yaitu sebagai berikut: Karena situasi pandemi Covid-19 saat ini Satlantas Polres Gianyar tidak secara penuh menegakkan hukum sesuai Undang-undang Nomor 22 Tahun 2009 tentang Lalu Lintas dan Angkutan Jalan, serta Peraturan Pemerintah Nomor 80 Tahun 2012 tentang Tata Cara Pemeriksaan Kendaraan Bermotor Di Jalan dan Penindakan Pelanggaran Lalu Lintas dan Angkutan jalan, namun lebih kepada memberikan pembinaan maupun hukuman fisik berupa push up atau squat jump agar memberikan efek jera terhadap pelanggar.

\section{Saran}

Saran saya kepada masyarakat yang memodifikasi kendaraan bermotor agar sesuai dengan peraturan yang berlaku, agar kendaraan tersebut aman dan layak untuk digunakan di jalan raya, serta tidak membahayakan pengendara tersebut maupun pengendara yang lainnya.

Saran saya kepada pihak yang berwenang yaitu kepolisian khususnya Satlantas Polres Gianyar agar dalarn menindak pelanggaran lalu lintas khususnya modifikasi kendaraan bermotor lebih tegas, sebab masyarakat kurang menyadari akan hukum lalu lintas serta masyarakat mengganggap hukum itu hal yang sepele.

\section{DAFTAR PUSTAKA}

Ali, A. (2002). Menguak Tahir Hukum. Toko Gunung Agung, Jakarta.

Kristiyanti, C. T. S. (2018). Hukum perlindungan konsumen. Sinar Grafika, Jakarta.

M. N. Nasution. (2008). Manajemen Transportasi. Ghalia Indonesia, Bogor.

Soemitro, R. H. (1990). Metodologi penelitian hukum. Ghalia Indonesia, Jakarta

Ali, Zainuddin. (2014). Metode Penelitian Hukum. Sinar Grafika, Jakarta.

Efendi, J., \& Ibrahim, J. (2016). Metode Penelitian Hukum: Normatif dan Empiris. Kencana, Jakarta. Fajar, Mukti; Achmad, Y. (2015). Dualisme Penelitian Hukum (Normatif \& Empiris). Pustaka Pelajar. Yogyakarta.

Matthews, S. Y. Y. (2020). Pengaturan Modifikasi Kendaraan Bermotor Di Indonesia. Jurnal Kertha Semaya, Vol. 8(5).

Mahasin, A. N. (2019). Praktik Custom Motor Ditinjau dari Hukum Positif dan Hukum Islam (Studi Kasus di Bengkel Icus Custom Desa Ngasem Krajan Kecamatan Bandungan Kabupaten Semarang). Program Studi Hukum Ekonomi Syari'ah Fakultas Syari'ah Institut Agama Islam Negeri (Iain) Salatiga.

Mahdi, I. (2016). Alasan Modifikasi Motor Ditinjau dari Pasal 132 Peraturan Pemerintah Nomor 55 Tahun 2012 dan Maslahah Mursalah. Jurusan Hukum Bisnis Syariah, Fakultas Syariah. Universitas Islam Negeri Maulana Malik Ibrahim. 